\title{
ANALISIS PENDAPATAN ASLI DAERAH (DARI SEKTOR RETRIBUSI) PADA DINAS PERHUBUNGAN DI KABUPATEN CIAMIS
}

\author{
Oleh: \\ Rully Noor Oktaviana \\ Program Studi Pendidikan Ekonomi \\ Fakultas Ilmu Pendidikan dan Pengetahuan Sosial \\ Universitas Indraprasta Jakarta \\ Email: \\ ully.unpad@gmail.com
}

\begin{abstract}
ABSTRAK
Penelitian ini bertujuan untuk untuk menganalisa Pendapatan Asli Daerah dari sektor retribusi pada Dinas Perhubungan Kabupaten Ciamis sudah berjalan sesuai aturan (Perda) yang berlaku atau belum). Penelitian ini merupakan penelitian deskriptif kualitatif, dilakukan dengan cara menganalisis konsep, kebijakan, serta hasil survey atas persepsi pihak-pihak yang terkait dalam kajian mengenai potensi pajak dan retribusi daerah yang diharapkan memberikan kontribusi terhadap PAD di Kabupaten Ciamis. Hasil penelitian menunjukkan bahwa retribusi pada Dinas Perhubungan Kabupaten Ciamis memiliki masalah yang signifikan terbukti dari hasil data yang diperoleh.
\end{abstract}

Kata Kunci : Pendapatan Asli Daerah, Retribusi, Dinas Perhubungan

\section{A. PENDAHULUAN}

Ketersediaan fasilitas dan sarana publik di suatu daerah yang digunakan oleh masyarakat adalah bukti bahwa adanya anggaran dalam pengadaannya. Terlepas dari baik atau tidak nya fasilitas tersebut menunjukkan bahwa anggaran yang digunakan masih belum optimal. Anggaran tesebut diperoleh dari penerimaan daerah yang berasal dari pajak dan retribusi sebagai kontribusi dalam Pendapatan Asli Daerah (PAD).

Penelitian ini spesifik pada retribusi terutama pada Dinas Perhubungan Kabupaten Ciamis. Hal ini menjadi kajian utama karena Ciamis sebagai daerah wisata tentunya memiliki fasilitas atau sarana yang menunjang dalam pelayanannya. Semakin baik sarana perhubungan maka semakin bertambah daya tarik wisatawan dalam berkunjung dan tentunya masyarakat setempat dapat menikmati fasilitas tersebut dalam kegiatannya sehari hari terutama dalam bekerja sehingga dapat mendatangkan manfaat secara ekonomi dan mensejahterakan masyarakat sekitar. Sebagaimana yang dikutip Shahreza,Dhona. (2014). Supply and Demand Identification of Ecotourism Sector. Journal of Applied Business and Economics , 1, 1. mengatakan bahwa 
" the application or regional autonomy provides logic consequency toward regional government to handle their households has their responsibilities fully in enhancing the prosperity of their people through activity of tourism development " hal senada juga diungkapkan oleh Siregar (dalam Shahreza, dhona. (2014). Supply and Demand Identification of Ecotourism Sector. Journal of Applied Business and Economics , 1, 1.)

"Tourism in many developing countries including Indonesia has a significant role in solving the poverty problem, i.e. through absorption of manpower and increase of income.

Berdasarkan survey di lapangan melalui hasil wawancara dengan warga, Masyarakat terkadang kurang memahami arti dari retribusi dan sumber dana pengadaan fasilitas tersebut, sehingga sebagian besar dari mereka belum menaati aturan dalam pembayaran retribusi. Mereka menganggap bahwa pembayaran atau pungutan yang selama ini ada adalah sejenis pungutan liar yang tidak mendatangkan manfaat. Ini sebaiknya menjadi tugas besar pemerintah daerah setempat dalam mensosialisasikan reribusi beserta peraturan dan sanksinya.

Tujuan dari penelitian ini adalah menganalisa retribusi sebagai bagian dari Pendapatan Asli Daerah khususnya pada dinas perhubungan dari sisi target dan realisasinya, serta bagaimana peraturan daerah yang ada dalam penerapannya dimasyarakat, agar terbentuk langkah atau solusi dalam penanganannya dari pemerintah dan pihak terkait agar kondisi berjalan sebagaimana mestinya.

\section{B. KAJIAN PUSTAKA}

\section{Pembangunan Ekonomi Daerah}

"Pembangunan merupakan suatu proses multidimensi, dimana pelaksanaan pembangunan selalu berusaha untuk melakukan pengorganisasian kembali (re-organization) dan juga pengorientasian kembali (re-orientation) dari sistem sosial dan ekonomi secara keseluruhan" (M.P,Todaro, 2000) Pembangunan yang dilaksanakan oleh suatu pemerintahan ditujukan untuk mencapai suatu kondisi tertentu, yaitu meningkatkan kesejahteraan masyarakat. Cara yang dilakukan adalah dengan sistem desentralisasi, dimana pemerintah daerah, kabupaten atau kota diberi kesempatan untuk mengoptimalkan potensi kekayaan alam dan sumber keuangan lainnya salah satu diantaranya adalah mengelola retribusi.

Retribusi menurut UU Nomor 28 tahun 2009 adalah pungutan daerah sebagai pembayaran atas jasa atau pemberian izin tertentu yang khusus disediakan dan/atau diberikan oleh pemerintah daerah untuk kepentingan pribadi atau badan. Retribusi berkontribusi terhadap Pendapatan Asli Daerah (PAD) sehingga besar kecilnya retribusi akan berpengaruh terhadap jumlah PAD.

"Pembangunan harus dilihat dari sisi proses memperluas kebebasan masyarakat untuk mencapai kebahagiannya, sehingga fokus utama dari pembangunan adalah bagaimana menciptakan kebebasan manusia" (Amartya Sen, Development As Freedom, 2000 dalam (Wardhana, Sukartawinata, Oktaviana, 2013)). 
"Suatu proses saat pemerintah daerah dan masyarakat mengelola sumber daya yang ada dan selanjutnya membentuk suatu pola kemitraan antara pemerintah daerah dengan sektor swasta untuk menciptakan suatu lapangan kerja baru dan merangsang perkembangan kegiatan ekonomi (pertumbuhan ekonomi) dalam wilayah tersebut. Tujuan dari pembangunan ekonomi lokal (Local Economic Development) adalah untuk membangun kemampuan ekonomi daerah setempat untuk memperbaiki masa depan ekonomi dan kualitas hidup untuk semua. Ini adalah proses dimana masyarakat, bisnis dan sektor non-pemerintah mitra bekerja secara kolektif untuk menciptakan kondisi yang lebih baik bagi pertumbuhan ekonomi dan penciptaan lapangan kerja." (Ananda, c. Fajri, 2016)

Pada akhirnya, dengan pembangunan akan terjadi berbagai perubahan yang mendasar, baik pada kehidupan ekonomi, sosial budaya, maupun dalam kelembagaan/institusi. Pembangunan yang berhasil telah mengantarkan daerah menjadi daerah yang maju (developed region) dan sebaliknya keterlambatan dalam pembangunan menjadikan daerah tersebut tetap sebagai daerah yang terbelakang (under developed region).

Paradigma pembangunan manusia ini memiliki 4 (empat) pilar pokok (UNDP, 1995:129 (dalam (Wardhana, Sukartawinata, Oktaviana, 2013)), dimana ke empat pilar pokok ini dapat menjamin tercapainya tujuan pembangunan manusia seutuhnya. Secara ringkas 4 (empat) pilar pokok tersebut mengandung prinsip-prinsip sebagai berikut:

1. Produktivitas (productivity)

Produktivitas memerlukan investasi pada manusia, serta suatu keadaan makroekonomi yang memungkinkan penduduk untuk mengembangkan dirinya secara maksimal.

2. Pemerataan (equity)

Penduduk harus memiliki kesempatan yang sama untuk mendapat akses terhadap semua sumberdaya ekonomi dan sosial.

3. Kesinambungan (sustainability)

Akses terhadap sumber daya ekonomi dan sosial hendaknya harus terus berlanjut tidak hanya untuk generasi sekarang saja, akan tetapi diharapkan akses tersebut dapat dinikmati juga untuk generasi-generasi yang akan datang.

4. Pemberdayaan (empowerment)

Konsep yang komprehensif dari pemberdayaan dalam paradigma ini berarti penduduk dapat melaksanakan pilihan-pilihan sesuai dengan keinginannya.Halini berarti kebebasan bagi penduduk untuk menentukan keputusan-keputusan bagi kehidupannya.Tidak lain, ini sejalan dengan desentralisasi dan peran aktif dari masyarakat madani untuk ikut berpartisipasi dalam membuat dan mengimplementasikan berbagai kebijakan.

\section{Peran Pemerintah dalam Pembangunan}

Peran pemerintah dalam perekonomian dalam rangka pelaksanaan pembangunan bukan hanya berusaha membelanjakan berbagai penerimaan yang sudah didapat dari sistem perpajakan yang ada, akan tetapi lebih jauh dari hal tersebut. Terkadang pemerintah harus berupaya untuk memperbaiki berjalannya institusi atau "rule of the game" yang ada dalam perekonomian, sehingga bisa 
menjamin peran institusi dalam peningkatan pertumbuhan ekonomi. Salah satu upaya pemerintah dalam pengembangan institusi adalah berusaha agar mekanisme pasar bisa tetap menjadi salah satu faktor utama yang mendorong berbagai aktivitas kegiatan masyarakat yang pada akhirnya nanti bisa meningkatkan pertumbuhan ekonomi.

Oleh sebab itu dalam literatur ekonomi publik, peran/fungsi pemerintah di bidang ekonomi bisa dibedakan dalam tiga jenis, yaitu:

1. Fungsi alokasi. Tujuan utama dari fungsi ini adalah bagaimana pemerintah melalui berbagai kegiatan yang dilakukannya berupaya untuk membuat agar alokasi sumberdaya perekonomian bisa berjalan secara efisien.

2. Fungsi distribusi. Fungsi ini selalu dikaitkan dengan upaya-upaya pemerintah dalam berusaha untuk mewujudkan keadilan dalam pembangunan. Salah satu bentuk keadilan pembangunan adalah terciptanya distribusi pendapatan yang lebih merata diantara masyarakatnya.

3. Fungsi stabilisasi. Tugas pemerintah dalam berusaha untuk mewujudkan tujuan makro ekonomi, pertumbuhan ekonomi yang tinggi, stabilitas harga, dan mengatasi masalah pengangguran bisa dilakukan melalui dua paket kebijakan ekonomi yaitu kebijakan fiskal dan moneter. (Wardhana, Sukartawinata, Oktaviana, 2013)

Mendeteksi dua faktor kemungkinan dari ketiga fungsi pemerintah di atas. Menurut mereka, "fungsi stabilitas secara umum lebih baik jika dijalankan oleh pemerintah pusat (sentralistik), sedangkan fungsi alokatif dan distributif lebih baik dijalankan oleh pemerintah daerah. Hanya saja fungsi distributif ini lebik baik jika dijalankan oleh pemerintah pusat, sebab didalamnya ada unsur keadilan nasional harus dicapai', (Musgrave and Musgrave, 1989).

Terkait dengan fungsi stabilitas, jika bidang ini didesentralisasikan akan menjadi chaos terhadap sistem pemerintahan dan pengelolaan ekonomi daerah. Tidak menutup kemungkinan masing-masing daerah menetapkan instrumen fiskal dan moneter yang berbeda. Jika itu dilakukan maka masyarakat secara keseluruhan akan dirugikan. Atau dalam konteks pertahanan keamanan, apabila fungsi ini diserahkan kepada daerah, maka setiap daerah memiliki standar dan prosedur sistem pengamanan yang berbeda. Sedangkan fungsi distribusi, meskipun hal ini baiknya dijalankan oleh pemerintah daerah, namun demikian kapasitas dan potensi setiap daerah yang ada di Indonesia berbeda-beda, sehingga fungsi distributif lebih baik dijalankan oleh pusat agar terjadi distribusi sumber daya yang adil (Wardhana, Sukartawinata, Oktaviana, 2013).

Salah satu upaya pemerintah/pemerintah daerah untuk menjalankan fungsi otonominya dalam rangka meningkatkan pembangunan ekonomi daerah setempat maka retribusi dibebankan kepada masyarakat sebagai penikmat layanan publik, mengingat bahwa masyarakat Ciamis sebagian besar bergerak pada sektor pertanian dan wirausaha sebagai mata pencahariannya dan Ciamis sebagai daerah wisata maka diharapkan retribusi dari sarana perhubungan sebagai alat mobilitas sehari-hari dapat memberikan kontribusi yang maksimal pada PAD Ciamis untuk meningkatkan pembangunan daerah. 
Sejak otonomi daerah diberlakukan pada tahun 2001, Kabupaten Ciamis mengalami pemekaran wilayah menjadi Kabupaten Ciamis dengan 30 kecamatan dan Kota Banjar 4 kecamatan. Seiring dengan peningkatan jumlah penduduk di Kabupaten Ciamis dan untuk mengurangi rentang kendali pemerintahan pada tahun 2006 di Kabupaten Ciamis mengalami pemekaran sebanyak 6 kecamatan, sehingga dari 30 kecamatan menjadi 36 kecamatan. Begitu juga untuk jumlah desa, selama periode 2007 - 2009, jumlah desa bertambah sebanyak 3 desa. Demikian juga untuk periode yang sama jumlah Rukun Warga (RW) dan Rukun Tetangga (RT) mengalami penambahan sebanyak 27 Rukun Warga (RW) dan 92 Rukun Tetangga (RT) (Pemerintah Provinsi Jawa Barat, 2017).

Nurhastuti ( dalam (Surahmat, 2013) Untuk membangun perekonomian yang tangguh dan berdaya saing dengan memanfaatkan secara optimal potensipotensi unggulan. Peningkatan pertumbuhan sektor pertanian secara signifikan yang diharapkan dapat mendongkrak pertumbuhan ekonomi dengan mengembangkan program-program yang mempunyai daya ungkit bagi pertumbuhan ekonomi. Selain itu, Sektor industri pengolahan dan perdagangan diarahkan untuk memanfaatkan produk-produk unggulan daerah, khususnya produk pertanian. Meningkatkan pembangunan infrastruktur strategis yang mendukung pertumbuhan ekonomi dan pengembangan aktifitas sosial budaya, khususnya melalui peningkatan kualitas jalan dan jembatan, rehabilitasi irigasi, pembangunan sarana dan prasarana perekonomian, serta pengembangan sarana dan prasarana perkantoran. Harapannya Musrenbang tahun 2013 bisa mengurangi kesenjangan pembangunan antar wilayah melalui distribusi pembangunan secara adil dan merata. Selain itu juga bisa meningkatkan pemberdayaan masyarakat dan desa, mengembangkan pembangunan daerah yang berorientasi terhadap pengurangan kemiskinan, pengangguran, pertumbuhan ekonomi dan pelestarian lingkungan hidup. Serta meningkatkan kemampuan keuangan daerah untuk dapat mendanai kebutuhan pembangunan daerah.

\section{METODE PENELITIAN}

Penelitian ini merupakan penelitian deskriptif kualitatif. Penelitian deskriptif kualitatif dilakukan dengan cara menganalisis konsep, kebijakan, serta hasil survey atas persepsi pihak-pihak yang terkait dalam kajian mengenai potensi pajak dan retribusi daerah yang diharapkan memberikan kontribusi terhadap Pendapatan Asli Daerah di Kabupaten Ciamis.

Populasi penelitian ini adalah seluruh kecamatan di Kabupaten Ciamis. Untuk mendapatkan data yang bersifat kualitatif, teknik sampling yang digunakan adalah purposive sampling method, yaitu pengambilan sampel yang terpilih menurut ciri-ciri khusus yang dimilikinya atau berdasarkan penilaian tertentu (Koentjaraningrat, 1994, p. 89)

Sampel yang diambil ditentukan tidak berdasarkan representasi sampel dalam sebuah populasi, tetapi berdasarkan kebutuhan data atau informasi yang hendak dikumpulkan. Individu yang dianggap dapat menjadi narasumber potensial dalam kajian ini (SKPD dan instansi terkait lainnya, asosiasidan masyarakat) akan menjadi sumber informasi/narasumber penelitian. 
Data yang diperoleh meliputi data primer dan sekunder. Data primer berupa hasil wawancara dan kuesioner dengan berbagai elemen yang menjadi sampel penelitian. Data sekunder berupa data literatur dari instansi terkait serta data lainnya yang relevan, baik yang diperoleh dari pemerintah yang bersangkutan ataupun dengan cara men-download data dari sumber data lainnya.

\section{HASIL DAN PEMBAHASAN}

Pelaksanaan pemungutan pajak daerah dan retribusi daerah dilakukan melalui produk hukum berupa peraturan daerah, selanjutnya disingkat dengan sebutan Perda. Pada sisi lain berjalannya pelaksanaan otonomi yang seluasluasnya bagi daerah dalam membiayai daerah, memberikan peluang untuk menggali potensi daerah melalui pungutan daerah berupa pajak daerah dan retribusi daerah sebagai sumber Pendapatan Asli Daerah ke dalam penetapan kebijakan hukum berupa Perda.

\section{Sumber-sumber Pendapatan Daerah}

Sumber penerimaan dana Pemerintah Daerah berdasarkan UU Nomor. 33/2004 terdiri atas:

1. Pendapatan Daerah

a. PAD, yang terdiri atas;

1. Pajak Daerah

2. Retribusi Daerah

3. Hasil pengelolaan kekayaan daerah yang dipisahkan

4. Lain-lain PAD yang sah

b. Dana Perimbangan, yang terdiri atas;

1. Dana Bagi Hasil

2. Dana Alokasi Umum

3. Dana Alokasi Khusus

c. Lain-lainpendapatan daerah yang sah

2. Pembiayaan

a. Sisa lebih perhitungan anggaran daerah

b. Penerimaan pinjaman daerah

c. Dana cadangan daerah

d. Hasil penjualan kekayaan daerah yang dipisahkan

Pendapatan Asli Daerah adalah penerimaan yang diperoleh dari sektor pajak daerah, retribusi daerah, hasil perusahaan milik daerah, hasil pengeloalaan kekayaan daerah yang dipisahkan, dan lain-lain Pendapatan Asli Daerah yang sah. Pendapatan Asli Daerah (PAD) merupakan salah satu komponen sumber pendapatan daerah sebagaimana yang telah diatur dalam Undang-undang Nomor 22 pasal 79 tahun 1999 tentang pemerintahan daerah, dapat disimpulkan bahwa sesuatu yang diperoleh pemerintah daerah yang dapat diukur dengan uang karena kewenangan (otoritas) yang diberikan masyarakat dapat berupa hasil pajak daerah dan retribusi daerah. 
Dalam Undang-undang Nomor 22 tahun 1999 pasal 79 tentang pemerintahan daerah mengisyaratkan bahwa dalam penyelenggaraan fungsifungsi pemerintahan daerah, kepala daerah Kabupaten/Kota diharapkan kepada kepala daerah Kabupaten/Kota dalam penyelenggaraan pemerintahan dan pelaksanaan pembangunan daerah tidak terus menerus selalu menggantungkan dana (anggaran) dari pusat melalui pembagian dana perimbangan. Dalam administrasi keuangan daerah PAD adalah pendapatan daerah yang diurus dan diusahakan sendiri oleh daerah yang dimaksud sebagai sumber PAD guna pembangunan. Berdasarkan ketentuan maka PAD dapat disimpulkan sebagai:

a. PAD merupakan sumber pendekatan daerah dengan mengelola dan memanfaatkan potensial daerahnya.

b. Di dalam mengelola, mengolah dan memanfaatkan potensi daerah, PAD dapat berupa pemungutan pajak, retribusi dan lain-lain pendapatan daerah yang sah.

Dalam pelaksanaan otonomi daerah, sumber keuangan yang berasal dari Pendapatan Asli Daerah lebih penting dibandingkan dengan sumber-sumber diluar Pendapatan Asli Daerah, karena Pendapatan Asli Daerah dapat dipergunakan sesuai dengan prakarsa dan inisiatif daerah sedangkan bentuk pemberian pemerintah (non PAD) sifatnya lebih terikat. Dengan penggalian dan peningkatan Pendapatan Asli Daerah diharapkan pemerintah daerah juga mampu meningkatkan kemampuannya dalam penyelenggaraan urusan daerah. (No Name, 2011)

"PAD bertujuan untuk memberikan kewenangan kepada pemerintah daerah untuk mendanai pelaksanaan otonomi daerah sesuai dengan potensi daerah. Dana Perimbangan bertujuan untuk menciptakan keseimbangan keuangan antara Pemerintah Pusat dan Daerah dan antara Pemerintahan Daerah. Dana Perimbangan yang terdiri dari Dana Bagi Hasil dari penerimaan pajak dan SDA, Dana Alokasi Umum, dan Dana Alokasi Khusus merupakan sumber pendanaan bagi daerah dalam pelaksanaan desentralisasi, yang alokasinya tidak dapat dipisahkan satu dengan yang lain mengingat tujuan masing-masing jenis penerimaan tersebut saling mengisi dan melengkapi. Dana perimbangan bertujuan untuk mengurangi kesenjangan fiskal antara pemerintah dan pemerintah daerah ". (Wardhana, Sukartawinata, Oktaviana, 2013)

Selain pendapatan dari pajak daerah, pemerintah kabupaten/kota juga bisa mendapatan pendapatan asli daerahnya dari retribusi. Retribusi daerah adalah pungutan daerah sebagai pembayaran atas jasa atau pemberian izin tertentu yang khusus disediakan dan/atau diberikan pemerintah daerah untuk kepentingan pribadi atau badan. Oleh sebab itu sumber dana yang berhasil dikumpulkan dari retribusi harus dikembalikan untuk kepentingan peningkatan pelayanan yang disediakan oleh pemerintah. Prinsip utama dalam pengelolaan retribusi adalah cost-recovery.

\section{Tujuan Retribusi}

Retribusi daerah diharapkan menjadi salah satu sumber keuangan untuk pembiayaan penyelenggaraan pemerintah dan pembangunan daerah. Hal tersebut 
tak lain adalah guna meningkatkan dan mencapai pemerataan kesejahteraan masyarakat. Pada hakikatnya, pemungutan retribusi daerah memiliki persamaan pokok dalam hal tujuannya dengan pemungutan pajak, yaitu sebagai berikut :

1. Memenuhi kebutuhan rutin kas daerah atau negara yang merupakan tujuan utama

2. Menciptakan dan pemerataan kesejahteraan masyarakat yang merupakan tujuan tambahan.

\section{Sifat Retribusi}

Dalam pelaksanaannya, retribusi memiliki 2 sifat yaitu :

1. Retribusi yang bersifat umum. Bersifat umum berarti berlaku secara umum. Maksudnya, pungutan retribusi memiliki sifat berlaku umum bagi siapa pun yang ingin menikmati dan memperoleh manfaat dari jasa yang disediakan oleh pemerintah daerah.

2. Retribusi yang bersifat khusus atau memiliki tujuan. Sifat pungutan retribusi ini bertujuan untuk mendapatkan manfaat tertentu dari jasa yang disediakan oleh pemerintah daerah.

\section{Ciri-Ciri Retribusi} yaitu :

Retribusi memiliki beberapa ciri-ciri yang hampir sama dengan pajak,

1. Dipungut oleh pemerintah daerah

2. Merupakan iuran tidak wajib namun terdapat paksaan secara ekonomis. Artinya seseorang tidak akan dikenakan sanksi jika tidak membayar retribusi, namun dirinya tidak akan memperoleh pelayanan atas jasa yang disediakan pemerintah daerah.

3. Memiliki kontra prestasi

4. Dibebankan pada tiap-tiap perorangan atau badan yang menggunakan jasa yang telah disiapkan oleh negara atau pemda (Indah,Rini, 2016)

\section{Fungsi Retribusi}

\section{Sumber Pendapatan Daerah}

Jika daerah telah memiliki sumber pendapatan yang mampu memenuhi dan mencukupi kebutuhan pemerintah daerah, maka pemerintah pusat tidak lagi memiliki beban berat dalam tujuannya turut serta Retribusi memiliki fungsi yang sangat penting terhadap Pendapatan Asli Daerah (PAD). Di mana fungsi tersebut dapat diukur berdasarkan target capai pungutan retribusi. Apabila target pencapaiannya tinggi, maka fungsi retribusi terhadap PAD akan tinggi pula.

\section{Pengatur Kegiatan Ekonomi Daerah}

Kegiatan ekonomi akan berjalan dan dapat diatur dengan baik jika sumbersumber keuangan ada dan mencukupi. Demikian halnya dengan ekonomi di daerah, yang mana retribusi menjadi salah satu sumber keuangannya, sehingga 
pengaturan kegiatan ekonomi daerah pada pos-pos tertentu dapat dijalankan dengan baik dan lancar.

\section{Sarana Stabilitas Ekonomi Daerah}

Retribusi yang masuk ke kas daerah secara rutin akan menjadikan perekonomi daerah pada posisi stabil ekonomi karena biaya-biaya penyelenggaraan pemerintah daerah telah disokong oleh retribusi.

\section{Pemerataan Pembangunan dan Pendapatan Masyarakat}

Jika poin-poin di atas terpenuhi dengan adanya retribusi, maka pemerataan pada pembangunan dan pendapatan masyarakat akan tercapai yang sekaligus meningkatkan kesejahteraan serta taraf hidup masyarakat. Negara Indonesia terdiri dari berbagai macam daerah dengan sistem ekonomi desentralisasi. Jika semua fungsi di atas berjalan dan berlaku baik di tiap-tiap daerah di Indonesia, secara agregat akan memengaruhi perekonomian bangsa. Namun dalam pelaksanaannya di lapangan mungkin saja terjadi berbagai kendala atas pemungutan retribusi.

\section{Jenis Obyek Retribusi}

Tidak semua fasilitas pemerintah daerah dikenakan pungutan retribusi.Hanya jenis jasa tertentu yang layak ditetapkan sebagai obyek retribusi menurut pertimbangan sosial ekonomi. Adapun jenis obyek retribusi tersebut meliputi

\section{Jasa Pelayanan Umum}

Adalah jasa yang disediakan oleh pemerintah daerah untuk kepentingan umum dan dapat dinikmati oleh umum baik perorangan ataupun badan. Yang termasuk jasa pelayanan umum yaitu: Retribusi Pelayanan Kesehatan, Retribusi Pelayanan Pendidikan, Retribusi Pelayanan Kebersihan/Persampahan, Retribusi Pelayanan Pemakaman dan Penguburan Mayat, Retribusi Pelayanan Parkir di Tepi Jalan Umum, dan lain sebagainya. Yang tidak termasuk dalam jasa ini adalah jasa urusan umum pemerintah.

\section{Jasa Usaha}

Merupakan jasa yang disediakan pemerintah daerah dengan menganut prinsip komersial yang ditujukan untuk jasa usaha perorangan atau badan. Contoh jenis retribusi ini adalah: Retribusi Pasar Grosir dan/atau Pertokoan, Retribusi Tempat Penginapan/Pesanggrahan/Villa, Retribusi Terminal, Retribusi Tempat Rekreasi dan Olah raga, Retribusi Pemakaian Kekayaan Daerah, dan lain-lain.

\section{Jasa Perijinan Tertentu}

Pada dasarnya pemberian ijin oleh pemerintah tidak dikenakan pungutan retribusi. Namun bisa jadi pemerintah daerah masih mengalami kekurangan pendapatan yang tidak dapat dicukupi oleh sumber-sumber penerimaan daerahnya, sehingga untuk kondisi tersebut, perijinan tertentu dikenakan pungutan retribusi. Contohnya adalah: Retribusi Ijin Mendirikan Bangunan, Retribusi Ijin 
Usaha Perikanan, Retribusi Ijin Gangguan, Retribusi Ijin Tempat Penjualan Minuman Beralkohol, Retribusi Ijin Trayek. (Indah,Rini, 2016)

Tabel 1.

Data Target Retribusi Daerah dan Data Aktual Dinas Perhubungan Kabupaten Ciamis Tahun 2010-2012

\begin{tabular}{|c|r|r|r|}
\hline TAHUN & \multicolumn{1}{|c|}{ TARGET } & \multicolumn{1}{|c|}{ REALISASI } & $\begin{array}{c}\text { EFEKIVITAS } \\
\text { PENERIMAAN }\end{array}$ \\
\hline 2010 & $18,217,076,900.00$ & $10,937,885,750.00$ & 60.0419365 \\
\hline 2011 & $18,439,256,300.00$ & $8,782,707,660.00$ & 47.6304875 \\
\hline 2012 & $26,957,660,000.00$ & $11,615,886,507.00$ & 43.0893724 \\
\hline
\end{tabular}

Sumber : Pengolahan Data dari Dinas Perhubungan Kabupaten Ciamis

Data diatas menunjukkan bahwa antara target penerimaan dan realisasi terdapat beda atau kesenjangan yang cukup jauh. Hal ini dikarenakan sebagian besar masyarakat belum mentaati peraturan dalam pembayaran retribusi. Selain itu, belum ada sosialisasi sanksi yang tegas dari pemerntah, pengawasan yang ketat dan masyarakat kurang memahami manfaat retribusi. Permasalahan berikutnya yaitu keseragaman menggunakan Perda lama untuk memungut retribusi sedangkan Perda baru sudah disahkan/berlaku.

Efektivitas adalah perbandingan antara realisasi penerimaan retribusi daerah terhadap target penerimaannya. Hal ini menunjukkan apaah realisasi yang diterima mencapai atau mendekati targetnya. Adapun rumus yang digunakan dalam efektivitas adalah

$$
\text { Efektivitas }=(\text { realisasi } / \text { target }) \times 100
$$

Hasil yang didapat dalam bentuk presentase, sehingga dapat dikatakan bahwa efektivitas menghasilkan angka mendekati 100\% maka retribusi daerah semakin efektif. Tabel diatas menunjukkan bahwa efektivitas retribusi daerah pada Dinas Perhubungan Kabupaten Ciamis masih jauh dari 100\% atau dapat dikatakan belm efektif karna masih jauh dari target yan ditntukan.

Tabel 2.

Kontribusi Retribusi Daerah Dinas Perhubungan Kabupaten Ciamis Terhadap PAD Tahun 2010-2012

\begin{tabular}{|r|c|c|c|}
\hline TAHUN & $\begin{array}{c}\text { REALISASI } \\
\text { RETRIBUSI }\end{array}$ & $\begin{array}{c}\text { REALISASI } \\
\text { REKAPITULASI PAD }\end{array}$ & $\begin{array}{c}\text { KONTRIBUSI RETRIBUSI } \\
\text { TERHADAP PAD (\%) }\end{array}$ \\
\hline 2010 & $10,937,885,750.00$ & $1,318,623,298,748.00$ & 0.829492832 \\
\hline 2011 & $8,782,707,660.00$ & $1,599,795,624,968.00$ & 0.548989354 \\
\hline 2012 & $11,615,886,507.00$ & $1,867,433,341,771.00$ & 0.622024157 \\
\hline
\end{tabular}

Sumber : Data Dinas Perhubungan Kabupaten Ciamis dan pengolahan data

$$
\text { Kontribusi retribusi terhadap PAD }=\frac{\text { Realisasi Retribusi }}{\text { Realisasi PAD }} \times 100
$$


Berdasarkan tabel diatas dapat dikatakan bahwa kontribusi retribusi daerah Pada Dinas Perhubungan Kabupaten Ciamis terhadap Pendapatan Asli Daerah ( PAD ) masih rendah.

Ruang lingkup wilayah dalam kegiatan ini adalah keseluruhan wilayah Kabupaten Ciamis atau 26 Kecamatan yang berada di Wilayah Kabupaten Ciamis. Ditambah 10 Kecamatan yang ada di Daerah Otonom Baru (DOB) Kabupaten Pangandaran. Adapun peraturan yang digunakan adalah :

\section{Retribusi Daerah pada Dinas Perhubungan :}

1. Retribusi Parkir di Tepi Jalan

- Perda Nomor 13 Tahun 2011, Tanggal 27 September 2011

2. Retribusi Pengujian Kendaraan Bermotor

- Perda Nomor 4 Tahun 2012, Tanggal 6 Pebruari 2012

3. Retribusi Terminal

- Perda Nomor 15 Tahun 2011, Tanggal 27 September 2011

4. Retribusi Tempat Khusus Parkir

- Perda Nomor 14 Tahun 2011, Tanggal 27 September 2011

5. Retribusi Izin Trayek

- Perda Nomor 16 Tahun 2011, Tanggal 27 September 2011

Peraturan Daerah tentang Retribusi Terminal ( Perda Nomor 15 Tahun 2011, Tanggal 27 September 2011) disebutkan dalam pasal 3 yang menyatakan bahwa Objek Retribusi adalah pelayanan penyediaan fasilitas terminal meliputi :

1. Penyediaan tempat parkir untuk kendaraan umum dan bis umum

2. Tempat kegiatan usaha

3. Fasilitas lainnya di lingkungan terminal yang disediakan, dimiliki, dan/atau dikelola oleh pemerintah daerah.

Pada pasal 4 disebutkan bahwa Subjek Retribusi Terminal adalah orang pribadi atau badan yang menggunakan/ menikmati pelayanan terminal. Peraturan Daerah Kabupaten Ciamis tentang Retribusi Izin Trayek ( Perda Nomor 16 Tahun 2011, Tanggal 27 September 2011 ) disebutkan dalam Pasal 2 bahwadengan nama retribusi izin trayek dipungut retribusi sebagai pembayaran atas pemberian izin trayek untuk menyediakan pelayananangkutan umum, Pasal 3 menyebutkan bahwa obyek retribusi izin trayek adalah pemberian izin kepada orang pribadi atau badan untuk menyediakan pelayanan angkutan penumpang umumpada suatu atau beberapa trayek tertentu, dan Pasal 4 menyatakan bahwa subyek retribusi Izin trayek adalah setiap perorangan dan/atau badanhukum yang memperoleh izin trayek.

Peraturan Daerah Kabupaten Ciamis tentang Retribusi Pengujian Kendaraan Bermotor yaitu perda Nomor 4 tahun 2012 disebutkan dalam pasal 3 yaitu objek retribusi adalah pelayanan pengujian kendaraan bermotor yang meliputi mobil bus, mobil penumpang umum, mobil barang, kereta gandengan, kereta tempelan, kendaraan khusus. 
Peraturan Daerah Kabupaten Retribusi Tempat Khusus Parkir Perda Nomor 14 Tahun 2011, Tanggal 27 September 2011) disebutkan dalam pasal 2 yang termasuk dalam obyek retribusi adalah pelataran atau lingkungan parkir, taman parkir, dan gedung parkir. Selanjutnya yang tidak termasuk obyek retribusi parkir adalah tempat khusus parkir yang dimliki dan/atau dikelola oleh pemerintah, BUMD, BUMN, dan pihak swasta.

Peraturan Daerah Kabupaten Ciamis tentang Retribusi Parkir di Tepi Jalan (Perda Nomor 13 Tahun 2011, Tanggal 27 September 2011) prinsip dalam penetapan struktur dan besarnya reribusi disebutkan dalam pasal 6 ayat 1 bahwa tujuannya yaitu untuk mengendalikan permintaan dan penggunaan jasa pelayanan dalam rangka memperlancar lalu lintas jalan dengan tetap memperhatikan biaya penyelenggaraan pelayanan, kemampuan masyarakat dan aspek keadilan. Selanjutnya pada ayat 2 bahwa biaya yang dimaksud pada ayat 1 yaitu biaya pengadaan marka, pengadaan rambu-rambu, biaya operasional, pemeliharaan,administrasi, dan biaya transportasi dalam rangka pengawasan dan pengendalian. Struktur dan besarnya tarif retribusi dijelaskan dalam pasal 7 yaitu kendaraan bermotor bus/truck Rp 1.500/kendaraan/satu kali parkir, kendaraan bermotor sedan,jeep,mini bus, pick up dan sejenisnya Rp 1000/ kendaran/satu kali parkir, dan sepeda motor Rp 500/ kendaraan/satu kali parkir.

\section{E. SIMPULAN}

Hasil penelitian menyatakan bahwa retribusi pada Dinas Perhubungan Kabupaten Ciamis memiliki masalah yang signifikan terbukti dari hasil data yang diperoleh terihat bahwa target dan realisasi memiliki kesenjangan yang cukup jauh. Ini berarti bahwa potensi Pendapatan Asli Daerah Kabupaten Ciamis dari sektor retribusi pada Dinas Perhubungan belum tercapai dengan baik. Hal ini terjadi karena berdasarkan survey di lapangan melalui hasil wawancara dengan warga, masyarakat kurang memahami arti dari retribusi dan sumber dana pengadaan fasilitas tersebut, sehingga sebagian besar dari mereka belum menaati peraturan dalam pembayaran retribusi dan belum ada sosialisasi dari pemerintah mengenai sanksi yang tegas apabila mereka tidak menaati peraturan. Selain itu, mereka menganggap bahwa pembayaran atau pungutan yang selama ini ada adalah sejenis pungutan liar yang tidak mendatangkan manfaat. Permasalahan berikutnya yaitu keseragaman menggunakan Perda lama untuk memungut retribusi sedangkan Perda baru sudah disahkan/berlaku. 


\section{DAFTAR PUSTAKA}

Ananda, c. Fajri. (2016). Peran Pemerintah dalam Pembangunan Ekonomi Daerah. Malang, Jawa Timur, Jawa Timur/Indonesia: FE Universitas

Brawijaya.Dinas Perhubungan dan Dispenda Kabupaten Ciamis, Laporan Keuangan 2008

Indah,Rini. (2016, Desember 9). http://dosenekonom.com. Retrieved May 12, 2017, from http://dosenekonom.com: http://dosenekonom.com/ilmuekonomi/perpajakan/fungsi-retribusi

Koentjaraningrat . (1994). Metodologi Penelitian. Jakarta: Erlangga.

Musgrave and Musgrave. (1989). Public Finance in Theory and Practice (5 ed.). Mc-Graw Hill .

No Name. (2011, April 26). https://hukum2industri.wordpress.com. Retrieved May 11, 2017, from https://hukum2industri.wordpress.com:

https://hukum2industri.wordpress.com

Pemerintah Provinsi Jawa Barat. (2017). http://ciamiskab.go.id. (Pemerintah Provinsi Jawa Barat) Retrieved May 9, 2017, from http://ciamiskab.go.id: http://ciamiskab.go.id

Perda Kabupaten Ciamis Nomor 13 Tahun 2011, Tanggal 27 September 2011tentang Retribusi Parkir di Tepi Jalan

Perda Kabupaten CiamisNomor 4 Tahun 2012, Tanggal 6 Pebruari 2012,tentang retribusi Pengujian Kendaraan Bermotor

Perda Kabupaten Ciamis Nomor 15 Tahun 2011, Tanggal 27 September 2011tentangRetribusi Terminal

Perda Kabupaten Ciamis Nomor 14 Tahun 2011, Tanggal 27 September 2011tentang Retribusi Tempat Khusus Parkir

Perda Kabupaten Ciamis Nomor 16 Tahun 2011, Tanggal 27 September 2011 tentang Retribusi Izin Trayek

Surahmat. (2013). http://www.sapa.or.id. Retrieved May 9, 2017, from http://www.sapa.or.id: http://www.sapa.or.id

Shahreza,Dhona. (2014). Supply and Demand Identification of Ecotourism Sector. Journal of Applied Business and Economics , 1, 1.

Todaro,M.P. (2000). Pembangunan Ekonomi di Dunia Ketiga. Pembangunan Ekonomi di Dunia Ketiga (5 ed.). Jakarta: Erlangga.

UU Nomor 28 tahun 2009 tentang Retribusi 
Undang-undang Nomor 33 Tahun 2004 tentang "Perimbangan Keuangan Antara Pusat dan Daerah".Jakarta Sinar Grafika. 2004.

Undang-undang Nomor 22 pasal 79 tahun 1999 tentang Pemerintahan Daerah

Undang-undang No.18 Tahun 1997 tentang Pajak Daerah dan Retribusi Daerah.

Wardhana, Sukartawinata, Oktaviana. (2013). Pengkajian Potensi Pendapatan Asli Daerah Kabupaten Ciamis. Bandung: Unpad. 